\title{
Islam and World History: The Ventures of Marshall Hodgson
}

\author{
Edmund Burke III and Robert J. Mankin, eds. \\ Chicago: Univeristy of Chicago Press, 2018. 193 pages.
}

In Islam and World History: The Ventures of Marshall Hodgson, editors Edmund Burke III and Robert J. Mankin have provided a valuable service to the scholarly community by bringing together a series of insightful essays that place the creation of Hodgson's posthumous masterwork, The Venture of Islam, into a broader historical and intellectual context. Perhaps most importantly, this slim but comprehensive volume adds greatly to our understanding of Marshall Hodgson himself, a historian who famously argued for the importance of recognizing the scholarly pre-commitments of academics, by providing a remarkable biographical context in which to consider the deeper implications of his work.

Of the all books that have influenced the study of Islam and Muslims in the last century there is probably none more pivotal than Hodgson's The Venture of Islam. Edward Said's Orientalism has been more influential, and certainly more widely read. However, as has been often noted, Said was not interested in writing the history of Islam and Muslims, but rather in analyzing and criticizing the ways others had written that history in the context of colonialism and imperialism. On the other hand, Hodgson-who, as one of the contributors to this volume notes, proclaimed "there is no Orient" fully thirty years before the publication of Orientalism-did much more than provide a critique of the way in which the history of Muslims and Islam had been written. He not only challenged the binaries and essentialism that underpinned much of that scholarship, but also provided a brilliant alternative history of what he famously called "the Islamicate world" that many 
of us who teach and write in the field still believe to be unsurpassed. In so doing, he challenged many of the truisms involved in writing history-and, as the editors of Islam and World History point out, not only Islamic history, for Hodgson (perhaps more than any other single individual) helped to usher in the modern discipline of World History.

Notwithstanding his importance as a historian, Hodgson's impact is perhaps even more evident among scholars of Islam in the field of religious studies, than in history proper. This should not be surprising. As one of the contributors to Islam and World History notes, "it is the question of religion... which is at the heart of and gives rise to his reading of Islamic history" (140). Hodgson's impact on the study of the religion of Islam is truly remarkable. He either coined or familiarized numerous terms that have become commonplace among scholars of Islam including "Islamicate," "sharî‘a-mindedness," "ālid loyalism," and my personal favorite, "tarìqat Shi' ism." He effectively challenged many popular attitudes about Islam that linger even today: the Arabo-centrism of Islamic studies, the notion that Sunni sharī $a$-minded Islam somehow constitutes Islamic orthodoxy, the belief that Islamic civilization declined after the Mongol invasion of Baghdad... Unlike the majority of the Orientalist tradition that preceded him, Hodgson never wrote about Muslims as "the Other." Instead, he presented Islam and Islamicate civilization as manifestations of a shared common global humanity.

Hodgson's appreciation of the role of religion (and especially Islam) in history was largely rooted in his own personal spirituality and corollary political activism. As the contributors to this volume insist, the power of his writing about Islam is based in a humanism and universalism deeply rooted in his Quaker piety. In particular, Michael Geyer's remarkable essay, "The Invention of World History from the Spirit of Non-violent Resistance," helps us to understand how Hodgson's Quaker identity and corollary experience as a conscientious objector in World War Two impacted his view of human history and his profoundly ethical imperative to build a more just world. His radical sense of egalitarianism, grounded in his Quaker spirituality, fostered a deep appreciation for the universalist and egalitarian aspects of Islam as a religious tradition which he saw manifested both in the shari ${ }^{-} a$ and, more importantly, in Sufi and Shi'i mysticism.

While each of the essays in the collections has something of value to offer, some of them speak especially directly to our understanding of Islam as religion. For example, Abdesselam Cheddadi's chapter, entitled "Islamic History and World History: The Double Enterprise of Marshall G. S. 
Hodgson," masterfully sets up the book's larger discussion. In this essay, he insightfully argues that Hodgson "accomplished two amazing feats-writing a history of Islam disconnected from the dominant Eurocentrist narrative and adopting a world-historical viewpoint" and in so doing freed it from "the essentialist conceptions that put forward binary oppositions such as East/West, Tradition/Modernity" (19). Katja Naumann's "Decentering World History: Marshall Hodgson and the UNESCO Project" accentuates the tremendous achievement of Hodgson's work by placing it into the context of previous largely unsuccessful postwar attempts to construct a world history that might escape the Eurocentrism of earlier scholarship.

The final two chapters are of particular interest to scholars of Islam. Jocelyne Dakhlia's "Harems and Cathedrals: The Question of Gender and Sexuality in the Work of Marshall Hodgson," translated from the French by Edmund Burke, raises fascinating issues about the way Hodgson deals with issues of sex and gender and shines an important light on the possible limits of his egalitarianism. The final chapter, Faisal Devji's "The Problem of Muslim Universality," provides a crucial key for understanding Hodgson's focus on universality and egalitarianism within the Islamic tradition. In this essay, among other insights, Devji notes the interesting similarities and differences between Hodgson and the twentieth-century Muslim intellectual Muhammad Iqbal, two men who were in their own distinctive ways immersed in the tension between two sources of egalitarianism and universality within Islam (the esotericism of the Sufi and mystical Shi'i traditions and the shari ${ }^{-} a$ ). While some readers of Hodgson have seen him as privileging the shari' $a$ as the defining characteristic of the religion of Islam and the major repository of its egalitarian and universalizing impulses, Devji points to Hodgson's continuing focus on Islam's mystical traditions, especially those such as the Isma'ili tradition, that also were focuses of political and social action. For although Hodgson clearly understood and appreciated Islamic law as a source of personal piety, as a Quaker he also fully appreciated the more seemingly "antinomian" aspects of Islam, especially those that combined the mystical with the political. Devji brilliantly argues that Hodgson's project in The Venture of Islam describes the history of Islam as an ongoing conflict between two competing forms of universality. One was a fundamentally conservative view associated with Sunni Islam and rooted in the historical inheritance of scripture, prophetic tradition, and shari'a. The other more radical and esoteric view, associated with the Ismaili traditions, "entailed the subordination of everything that had been 
inherited to the intellect and thus to man" (160). Devji quotes Hodgson describing this latter view:

For not only do men, as microcosm, represent all realms of being; they absorb all other life, and in the end no life in all these realms is fully real except insofar as, in the spiritual world, it has become human. (160)

For Hodgson, this tension continued even following the Mongol conquest and the corollary destruction of Nizari Isma'ili political power. Freed from the stewardship of the Abbasid Empire, the shari'a evolved "to become an autonomous and potentially universal entity." Simultaneously, the challenge of Ismailism's universality injected "a passionately Shi'i sense of the inner life into it by way of Sufism" (161). Read in this way, the full scope of Islam as an evolving tradition as understood by Hodgson comes into clear focus.

In their introduction to this volume, its editors suggest that their readers "as a thought experiment, think of another major scholar whose name is principally associated with a textbook" (3). Indeed, Hodgson is unique among scholars of his stature in being remembered in this way. As a result, those of us who teach from The Venture of Islam come back to it year after year in our classes, reading and re-reading it again and again and discussing it anew with students. One should note that there are few texts of any kind that are so continuously rewarding in this way (let alone "textbooks"). Perhaps more importantly, as a result of its popularity as textbook, The Venture of Islam continues to live and breathe as few other academic books do. It continually provides new and important insights that make the text even richer and more meaningful. I would argue that this is one reason why Islam and World History is such an important and valuable book. While it certainly has value for students reading The Venture of Islam for the first time, and I can certainly see myself assigning specific chapters to them, it is especially valuable for those of us who teach from it. Islam and World History unlocks previously invisible aspects of an already familiar text, thereby enhancing our experience of it.

Vernon James Schubel Professor of Religious Studies and Asian and Middle East Studies Kenyon College, Gambier, OH 